\title{
Molecular Karyotype and Chromosomal Localization of Genes Encoding $\beta$-tubulin, Cysteine Proteinase, hsp 70 and Actin in Trypanosoma rangeli
}

\author{
CB Toaldo, M Steindel*, MA Sousa**, CC Tavares/ ${ }^{+}$
}

\begin{abstract}
Departamento de Biologia Celular e Genética, Universidade do Estado do Rio de Janeiro, Rua São Francisco Xavier 524 - PHLC, 20550-013 Rio de Janeiro, RJ, Brasil *Departamento de Microbiologia e Parasitologia, Universidade Federal de Santa Catarina, Florianópolis, SC, Brasil **Coleção de Tripanosomatídeos, Departamento de Entomologia, Instituto Oswaldo Cruz, Rio de Janeiro, RJ, Brasil
\end{abstract}

The molecular karyotype of nine Trypanosoma rangeli strains was analyzed by contour-clamped homogeneous electric field electrophoresis, followed by the chromosomal localization of $\beta$-tubulin, cysteine proteinase, $70 \mathrm{kDa}$ heat shock protein (hsp 70) and actin genes. The T. rangeli strains were isolated from either insects or mammals from El Salvador, Honduras, Venezuela, Colombia, Panama and southern Brazil. Also, T. cruzi CL-Brener clone was included for comparison. Despite the great similarity observed among strains from Brazil, the molecular karyotype of all $\mathrm{T}$. rangeli strains analyzed revealed extensive chromosome polymorphism. In addition, it was possible to distinguish $\mathrm{T}$. rangeli from T. cruzi by the chromosomal DNA electrophoresis pattern. The localization of $\beta$-tubulin genes revealed differences among T. rangeli strains and confirmed the similarity between the isolates from Brazil. Hybridization assays using probes directed to the cysteine proteinase, hsp 70 and actin genes discriminated $\mathrm{T}$. rangeli from T. cruzi, proving that these genes are useful molecular markers for the differential diagnosis between these two species. Numerical analysis based on the molecular karyotype data revealed a high degree of polymorphism among T. rangeli strains isolated from southern Brazil and strains isolated from Central and the northern South America. The T. cruzi reference strain was not clustered with any $\mathrm{T}$. rangeli strain.

Key words: Trypanosoma rangeli - karyotype - pulsed field gel electrophoresis - housekeeping genes genetic variability - phenogram

Trypanosoma rangeli (Kinetoplastida: Trypanosomatidae) is a parasite that can infect both domestic and wild mammals and triatomine insects. Its transmission to the vertebrate host mainly occurs by inoculation of infective metatrypomastigotes formed in the salivary glands of the insects. The geographical distribution of $T$. rangeli is overlapped with $T$. cruzi, the causative agent of Chagas disease, and comprises almost all the countries of South and Central America (Grisard et al. 1999b). Reports of T. rangeli in Brazil have been made from the northern region of the Amazon basin to the southern country, precisely in the State of Santa Catarina (Miles et al. 1983, Steindel et al.

\footnotetext{
Financial support: Universidade do Estado do Rio de Janeiro, Fiocruz and Capes

${ }^{+}$Corresponding author. Fax: +55-21-587.7377. E-mail: ctavares@uerj.br

Received 16 May 2000

Accepted 5 July 2000
}

1991, Coura et al. 1996). In contrast to T. cruzi, T. rangeli is considered non-pathogenic to the vertebrate host. However, T. rangeli is pathogenic to its insect vectors (D'Alessandro \& Saravia 1992). Single or mixed infections in both vertebrate and invertebrate hosts by these two trypanosome species might be expected and reinforces the needs of a correct specific identification.

High levels of cross reactivity between $T$. rangeli and T. cruzi observed in different immunological assays have been reported and may lead to misdiagnosis (Cuba Cuba 1998). These species can be distinguished by the morphology of some developmental stages (Vallejo et al. 1988, reviewed by Sousa 1999). The classic method for identification of $T$. rangeli is the finding of typical parasite forms in the haemolymph and/or salivary glands of infected triatomines and its transmission to susceptible hosts through biting (D'Alessandro 1976). In addition, biochemical, immunological and molecular methods have been used to characterize $T$. rangeli strains and to differentiate it from $T$. cruzi, such as isoenzyme electrophoresis (Miles et al. 1983), lectin agglutination (Schottelius et al. 1986), 
monoclonal antibodies (Acosta et al. 1991), polymerase chain reaction (PCR) (Coura et al. 1996) and pulsed field gel electrophoresis (PFGE) (Henriksson et al. 1996b).

A low degree of polymorphism has been shown by isoenzyme analysis of different $T$. rangeli isolates from the Brazilian Amazon basin (Miles et al. 1983), Colombia (Holguín et al. 1987), and Honduras (Acosta et al. 1991). On the other hand, strains from Panama revealed a high polymorphism by the same method (Kreutzer \& Souza 1981). Using DNA fingerprinting and RAPD analysis, Macedo et al. (1993) and Steindel et al. (1994) have demonstrated that $T$. rangeli isolated in southern Brazil were genetically distinct from $T$. rangeli isolated in Honduras, Colombia and Venezuela. These results are in accordance with previous results obtained by isoenzyme analysis of the same samples (Steindel et al. 1992). Recently, a review corroborated these findings based on results of indirect immunofluorescence, lectin agglutination, isoenzyme electrophoresis, RAPD, triatomine susceptibility and mini-exon gene analysis (Grisard et al. 1999b).

PFGE-based molecular karyotyping of several protozoan parasites such as Plasmodium sp. (Kemp et al. 1987), T. cruzi (Henriksson et al. 1990) and Leishmania sp. (Cruz et al. 1993) revealed a high degree of intraspecific polymorphism.

Molecular karyotyping associated with gene localization within chromosomes has been used as tools for identification and characterization of isolates and clones of trypanosomatids (Cano et al. 1995, Henriksson et al. 1996a). On this field, Henriksson et al. (1996b) have analyzed a reasonable number of $T$. rangeli samples using molecular karyotyping.

In this work $T$. rangeli strains isolated from distinct vectors, reservoirs and geographical regions of Central and South America were analyzed by contour-clamped homogeneus electric field (CHEF) electrophoresis and hybridized with housekeeping genes probes.

\section{MATERIALS AND METHODS}

Parasites - Nine T. rangeli strains isolated from different geographical regions of South and Central America and the T. cruzi CL-Brener clone were analyzed in this study. The parasite strains, geographical origins and sources are shown in the Table. All strains were maintained at $28^{\circ} \mathrm{C}$ in NNN + LIT supplemented with $20 \%$ heat-inactivated fetal bovine serum through weekly passages.

Preparation of chromosomal DNA - Parasites were harvested by centrifugation at $1,500 \mathrm{x} \mathrm{g}$ at $4^{\circ} \mathrm{C}$. The pellets were washed three times with PSG buffer (75 mM buffer phosphate $\mathrm{pH} 8.0,65 \mathrm{mM}$ $\mathrm{NaCl}, 1 \%$ glucose) and resuspended in PSG at $5 \mathrm{x}$ $10^{8}$ cells $/ \mathrm{ml}$. An equal volume of $1.5 \%$ low melting point agarose in PS buffer (PSG without glucose), pre-warmed to $37^{\circ} \mathrm{C}$, was added to the cells. The cell/agarose mixture was immediately distributed into a block mould generating small blocks of $2 \times 5 \times 4 \mathrm{~mm}\left(\right.$ at $\left.4^{\circ} \mathrm{C}\right)$, containing approximately $10^{7}$ parasites/block. Once solidified, the blocks were incubated with lysis solution ( $1 \%$ sodium laurylsarcosinate, $1 \mathrm{mg} / \mathrm{ml}$ proteinase $\mathrm{K}, 0.5 \mathrm{M}$ EDTA pH 9.0) at $48^{\circ} \mathrm{C}$ for $48 \mathrm{~h}$, and stored in 50 mM EDTA pH 8.0 at $4^{\circ} \mathrm{C}$.

$P F G E$ - Chromosomal DNA was electrophorezed at $12^{\circ} \mathrm{C}$ using a CHEF-DRIII ${ }^{\circledR}$ system (Bio-Rad, Richmond, USA). The different running conditions necessary to obtain a fine resolution for each chromosomal size class are described in the legend of Fig. 1.

As molecular size markers, chromosomes from Saccharomyces cerevisiae strain YNN295 and Hansenula wingei strain YB-4662-VIA (Bio-Rad, Richmond, USA) were used. Gels were stained with $0.5 \mu \mathrm{g} / \mathrm{ml}$ ethidium bromide for $20 \mathrm{~min}$ and

TABLE

Strains, hosts, geographical origins and sources of Trypanosoma cruzi and T. rangeli

\begin{tabular}{|c|c|c|c|c|c|}
\hline Species & Code & Host & Strain/Clone & Origin & Source \\
\hline T. cruzi & CT-IOC 005 & T. infestans & CL-Brener clone & Brazil & CT-IOC \\
\hline T. rangeli & CT-IOC 002 & Human & $\mathrm{R}-1625$ & El Salvador & CT-IOC \\
\hline T. rangeli & CT-IOC 174 & Human & H-9 & Honduras & Dr A Romanha - CPqRR \\
\hline T. rangeli & CT-IOC 038 & Human & $\mathrm{H}-14$ & Honduras & CT-IOC \\
\hline T. rangeli & CT-IOC 273 & Human & Macias & Venezuela & Dr M Steindel - UFSC \\
\hline T. rangeli & CT-IOC 271 & R. prolixus & Choachi & Colombia & Dr M Steindel - UFSC \\
\hline T. rangeli & CT-IOC 270 & E. dasithryx & SC-58 & Brazil & Dr M Steindel - UFSC \\
\hline T. rangeli & CT-IOC 272 & E. dasithryx & SC-61 & Brazil & Dr M Steindel - UFSC \\
\hline T. rangeli & CT-IOC 158 & Human & Pepita Gonzales & Panama & CT-IOC \\
\hline T. rangeli & CT-IOC 275 & Human & San Agustin & Colombia & Dr A Romanha - CPqRR \\
\hline
\end{tabular}

CT-IOC: Coleção de Tripanosomatídeos, Instituto Oswaldo Cruz, Fiocruz, Rio de Janeiro, Brazil; CPqRR: Centro de Pesquisas René Rachou, Belo Horizonte, Brazil; UFSC: Universidade Federal de Santa Catarina, Brazil 
photographed using an UV transilluminator using Polaroid 55 films. DNA was transferred to nylon filters (Hybond N®, Amersham, Sweden) by standard techniques (Southern 1975).

Probes and hybridization assays - The following probes were used: a $3.8 \mathrm{~Kb}$ fragment of the $L$. major $\beta$-tubulin gene - clone pLT-1 (Huang et al. 1984), the Lpcys 2 cysteine proteinase gene of $L$. pifanoi (Traub-Cseko et al. 1993), a 0.4 Kb EcoRI fragment containing $T$. cruzi hsp 70 coding sequence (De Carvalho et al. 1990) and a sequence of the $T$. cruzi actin gene (Paixão 1995). These probes were radiolabeled with $[\alpha-32 \mathrm{P}] \mathrm{dCTP}$ by the random priming method (Rediprime kit ${ }^{\circ}$, Amersham, Sweden). The nylon filters were prehybridized at $42^{\circ} \mathrm{C}$ for $3 \mathrm{~h}$ in $6 \times \mathrm{SSC}(1 \times \mathrm{SSC}=150 \mathrm{mM} \mathrm{NaCl}, 15 \mathrm{mM}$ Na3C6H5O7), 5 x Denhardt's solution ( $0.2 \%$ bovine serum albumin, $0.2 \%$ polyvinylpyrrolidone, $0.2 \%$ Ficoll), $0.5 \%$ SDS, $100 \mu \mathrm{g} / \mathrm{ml}$ of sonicated and denatured salmon sperm DNA and 50\% formamide. Hibridization was performed overnight at $42^{\circ} \mathrm{C}$. After that, filters were washed three times for 30 min using $1 \times \mathrm{SSC}, 0.5 \% \mathrm{SDS}$ at $42^{\circ} \mathrm{C}$ and exposed overnight at $-70^{\circ} \mathrm{C}$ to Kodak X-Omat ${ }^{\circledR}$ film in intensifying screens.

Numerical analysis - A schematic diagram showing the molecular karyotype of all strains studied was constructed. From these karyotype profiles that could be identified with confidence on the basis of their intensity and individuality, a numerical matrix based on the presence and absence of bands was built.

This data was compared using Jaccard's similarity coefficient to determine the proportion of mismatched bands between strains. Based on the similarity matrix, a dendrogram was built using the unweighted pair-group method (UPGMA). These numerical analysis were performed using the NTSYS-pc® software (Version 1.70, Exeter Software, Setauket, USA).

\section{RESULTS}

Molecular karyotype analysis - The result of the molecular karyotype analysis of nine $T$. rangeli strains and one $T$. cruzi strain by CHEF electrophoresis using four distinct conditions is shown in Fig. 1 and represented in Fig. 2. The ethidium bromide stained gels revealed that each strain has a unique karyotype, although the two strains from Brazil (SC-58 and SC-61) show a high similarity between each other. Some features are specific of those strains, as the presence of a small band of $390 \mathrm{~Kb}$ (Fig. 1A). This band is smaller than the observed for the other $T$. rangeli strains $(450 \mathrm{~Kb})$ as well as for the $T$. cruzi reference strain $(550 \mathrm{~Kb})$. A variable absence of bands was noted in each strain, ranging between 750 and $1050 \mathrm{~Kb}$, clearly visible in strains $\mathrm{H}-9 ; \mathrm{H}-$ 14; Macias and Choachi (Fig.1A). Another variable absence of bands above $1400 \mathrm{~Kb}$ is suggested in Fig. 1B and $1 \mathrm{C}$ and is evident in Fig.1D in the range of $1400 \mathrm{~Kb}-2500 \mathrm{~Kb}$ in all strains of $T$. rangeli. In the range between $2350-2700 \mathrm{~Kb}$ we observed a single chromosomal band in all $T$. rangeli strains, except in Pepita Gonzales, while in T. cruzi CL-Brener clone we detected two bands in the same range (Fig. 1D). In this Fig., the presence of DNA is noted in the compression zone corresponding to chromosomes larger than 3130 $\mathrm{Kb}$ that are not separated by this electrophoretic condition.

Chromosomal localization of genes - The chromosomal localization of $\beta$-tubulin, hsp 70, actin and cysteine proteinase genes in $T$. rangeli strains and in the T. cruzi CL-Brener clone obtained through Southern blots of CHEF gels is presented on a diagram (Fig. 2). In this diagram hatched boxes indicate those bands that showed hybridization with the four studied genes. The diagram was constructed based on ethidium bromide stained gels and represents the molecular karyotypes containing chromosomes smaller than $2700 \mathrm{~Kb}$.

Chromosomal localization of $\beta$-tubulin genes allowed the separation of $T$. rangeli strains in two distinct groups, while cysteine proteinase, hsp 70 and actin genes were useful to differentiate $T$. rangeli from $T$. cruzi.

$\beta$-tubulin - T. cruzi CL-Brener clone as well as six out of nine $T$. rangeli strains (R-1625, H-9, H14, Macias, Choachi and San Agustin) hybridized with the $\beta$-tubulin gene probe in the compression region above $1000 \mathrm{~Kb}$ (Fig. 3A).

The T. rangeli strains SC-58, SC-61 and Pepita Gonzales hybridized with the $\beta$-tubulin gene probe in chromosomal bands of 690 and $720 \mathrm{~Kb}$ (SC58); $690 \mathrm{~Kb}$ (SC-61) and $650 \mathrm{~Kb}$ (Pepita Gonzales) and also showed a weak hybridization in the compression zone (Fig. 3A).

Cysteine proteinase - Hybridization with the cysteine proteinase gene probe revealed bands of approximately $500 \mathrm{~Kb}$ in R-1625, H-9, H-14, Macias, Choachi, SC-58, SC-61 and San Agustin T. rangeli strains. All T. rangeli strains and T. cruzi hybridized with this probe at the compression region (Fig. 3B).

Hsp 70 - The presence of the hsp 70 genes was observed in $T$. rangeli strains in two chromosomal bands very close to each other, ranging from 950 $\mathrm{Kb}$ in Pepita Gonzales strain to $1200 \mathrm{~Kb}$ in R-1625 strain. In $T$. rangeli $\mathrm{H}-14$ and SC-61 strains the hsp 70 genes were detected in an unique chromosomal band of 1125 and $1050 \mathrm{~Kb}$, respectively. In T. cruzi, those genes were observed in a single 1500 $\mathrm{Kb}$ chromosomal band (Fig. 3C). 

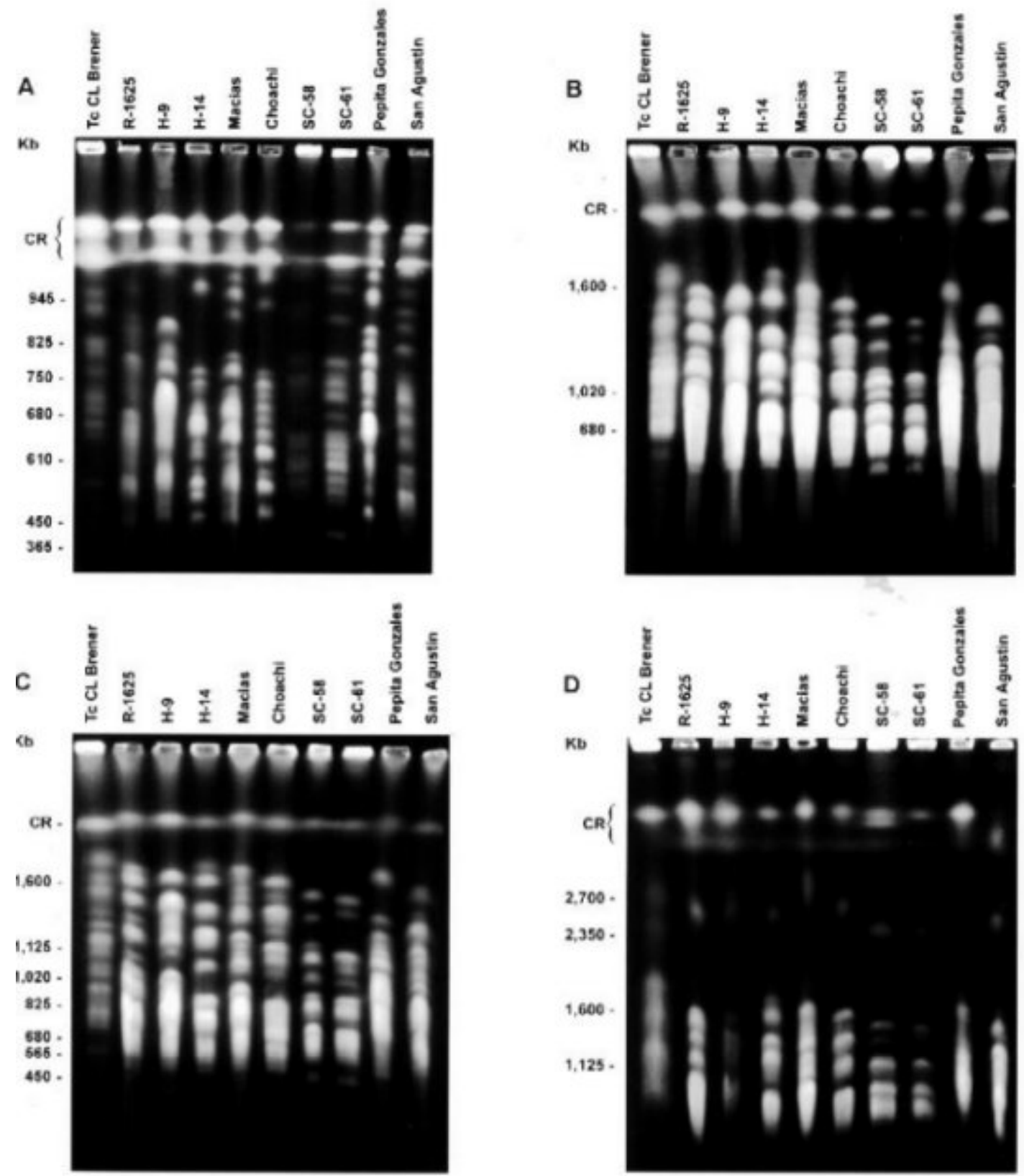

Fig. 1: molecular karyotype of Trypanosoma rangeli and T. cruzi isolates revealed after ethidium-bromide staining of contourclamped homogeneous electric field electrophoresis gel. Separation of chromosomes smaller than $1000 \mathrm{~Kb}$ was achieved using a $1.5 \%$ agarose gel in $0.5 \mathrm{x}$ TBE $(45 \mathrm{mM}$ Tris/45 mM boric acid/1 mM EDTA pH 8.0), pulse ramp: 100-50 s running time: $40 \mathrm{~h}$ field strength: $5.5 \mathrm{~V} / \mathrm{cm}$ field angle: $120^{\circ}$ (A). For chromosomes between 1000 and $2200 \mathrm{~Kb}$ two distinct conditions were used: a $1 \%$ agarose gel in $0.5 \mathrm{x}$ TBE, pulse ramp: $200-100 \mathrm{~s}$ running time: $24 \mathrm{~h}$ field strength: $5.5 \mathrm{~V} / \mathrm{cm}$ field angle: $120^{\circ}$ (B) and a $1 \%$ agarose gel in $0.5 \mathrm{x}$ TBE, pulse ramp: $200-50 \mathrm{~s}$ running time: $24 \mathrm{~h}$ field strength: $5.5 \mathrm{~V} / \mathrm{cm}$ field angle: $120^{\circ}(\mathrm{C})$. For chromosomes larger than $2200 \mathrm{~Kb}$ a $0.8 \%$ agarose gel in $1 \mathrm{x}$ TAE $(40 \mathrm{mM}$ Tris/40 mM glacial acetic acid/1 mM EDTA pH 8.0), pulse ramp: 500 s running time: $48 \mathrm{~h}$ field strength: $3.0 \mathrm{~V} / \mathrm{cm}$ field angle: $106^{\circ}(\mathrm{D})$ was used. The identities of samples are indicated on top of the gels, the T. cruzi sample is indicated with Tc, CR is compression region and the sizes of Saccharomyces cerevisiae and Hansenula wingei chromosomes are indicated on the left in kilobases pairs $(\mathrm{Kb})$. 

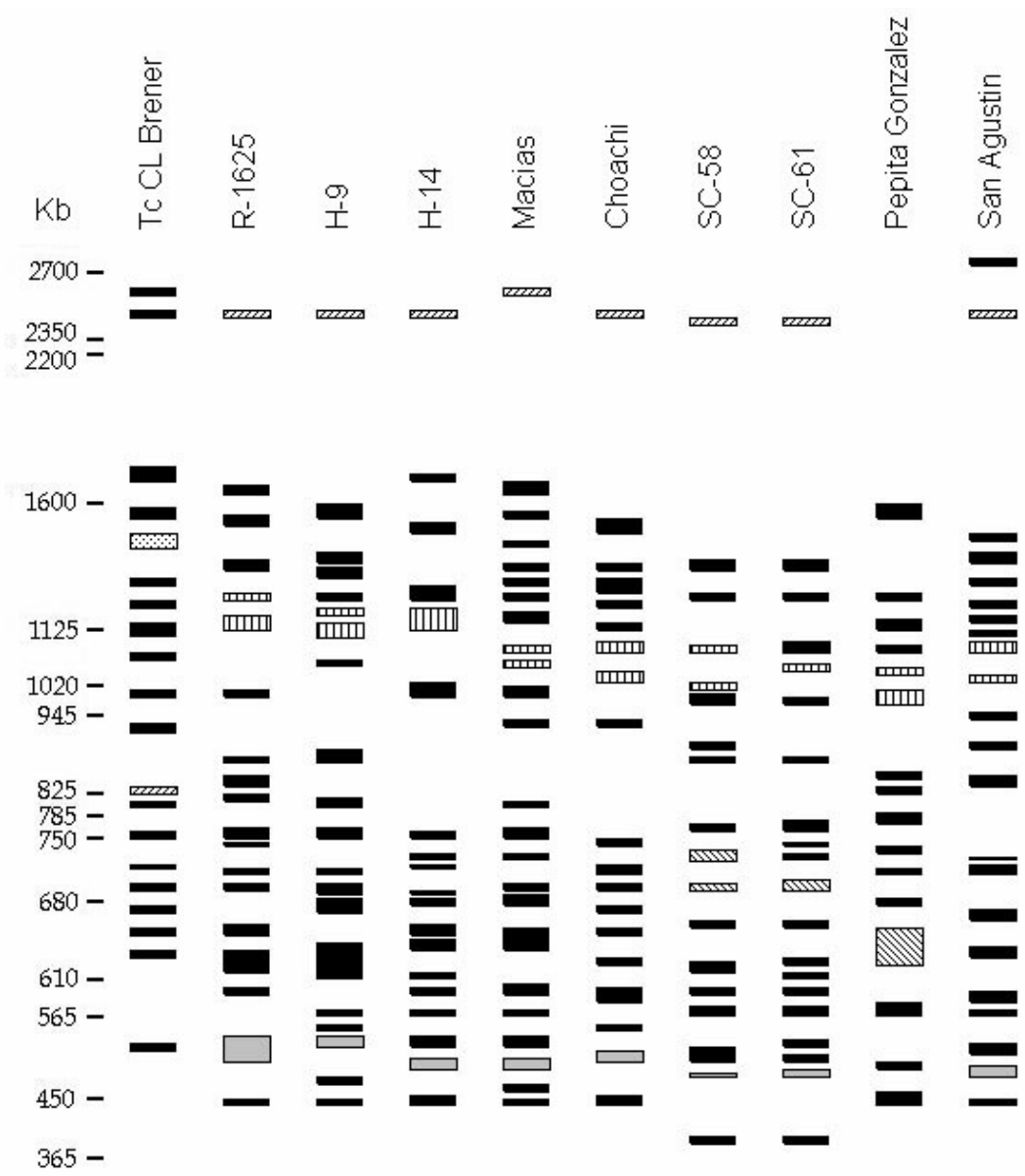

Fig. 2: diagrammatic representation of Trypanosoma rangeli and T. cruzi karyotypes. The identities of samples are indicated on top of the Figure. The T. cruzi sample is indicated with Tc. Chromosomes of Saccharomyces cerevisiae and Hansenula wingei were used as references and are indicated on the left in kilobases pairs $(\mathrm{Kb})$. Chromosomal localization of housekeeping genes

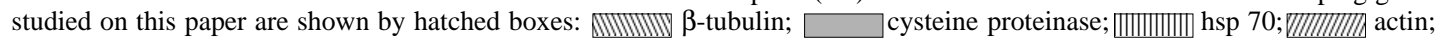

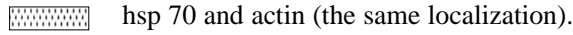

Actin - Actin genes were detected in $825 \mathrm{~Kb}$ and $1500 \mathrm{~Kb}$ chromosomal bands in T. cruzi and also in the compression region above $2200 \mathrm{~Kb}$ for all T. rangeli strains (Fig. 3D). Using electrophoretic conditions that separate the chromosomes larger than $2200 \mathrm{~Kb}$ we detected actin genes in an unique chromosomal band with sizes between 2350 and $2700 \mathrm{~Kb}$ in T. rangeli strains, except for Pepita Gonzales (data not shown) (Fig. 2).

Our results revealed the presence of hsp 70 and actin genes in the same $1500 \mathrm{~Kb}$ band in T. cruzi CL-Brener clone (Fig. 2), but despite the size we could not affirm that they are in the same chromosome.

Numerical analysis of molecular karyotypes Among different coefficients of similarity tested, Jaccard's coefficient showed to be the most ad- equate. Using data from the similarity matrix a dendrogram was constructed using UPGMA (Fig. 4). This phenetic tree showed that $T$. rangeli strains and $T$. cruzi CL-Brener clone were clearly clustered in different branches, indicating that $T$. cruzi and $T$. rangeli are genetically very distant. Among T. rangeli strains two distinct groups were formed: one containing the Colombian strains, Choachi and San Agustin (sub-branch 1) and another containing the other $T$. rangeli strains (sub-branch 2).

Sub-branch 2 was divided in other two subgroups: sub-branch $2 \mathrm{~A}$, including $T$. rangeli $\mathrm{R}$ 1625, H-9, H-14, Macias and Pepita Gonzales strains and sub-branch $2 \mathrm{~B}$ formed by $T$. rangeli strains isolated from the State of Santa Catarina, Brazil (SC-58 and SC-61), which showed similar molecular karyotypes (Fig. 1). 
Except for $T$. rangeli strains isolated from southern Brazil (SC-58 and SC-61), the molecular karyotype analysis among all $T$. rangeli strains revealed low similarity.

\section{DISCUSSION}

The molecular karyotype of nine $T$. rangeli strains was analyzed by CHEF electrophoresis us- ing four different electrophoretic conditions and revealed the presence of a great variability in the number and size of chromosomal bands. Henriksson et al. (1996b) detected chromosomal polymorphism in several $T$. rangeli strains, including some used in this work. The authors suggested that more than 20 chromosomal bands may be present in the different strains. Tanaka et al. (1994)
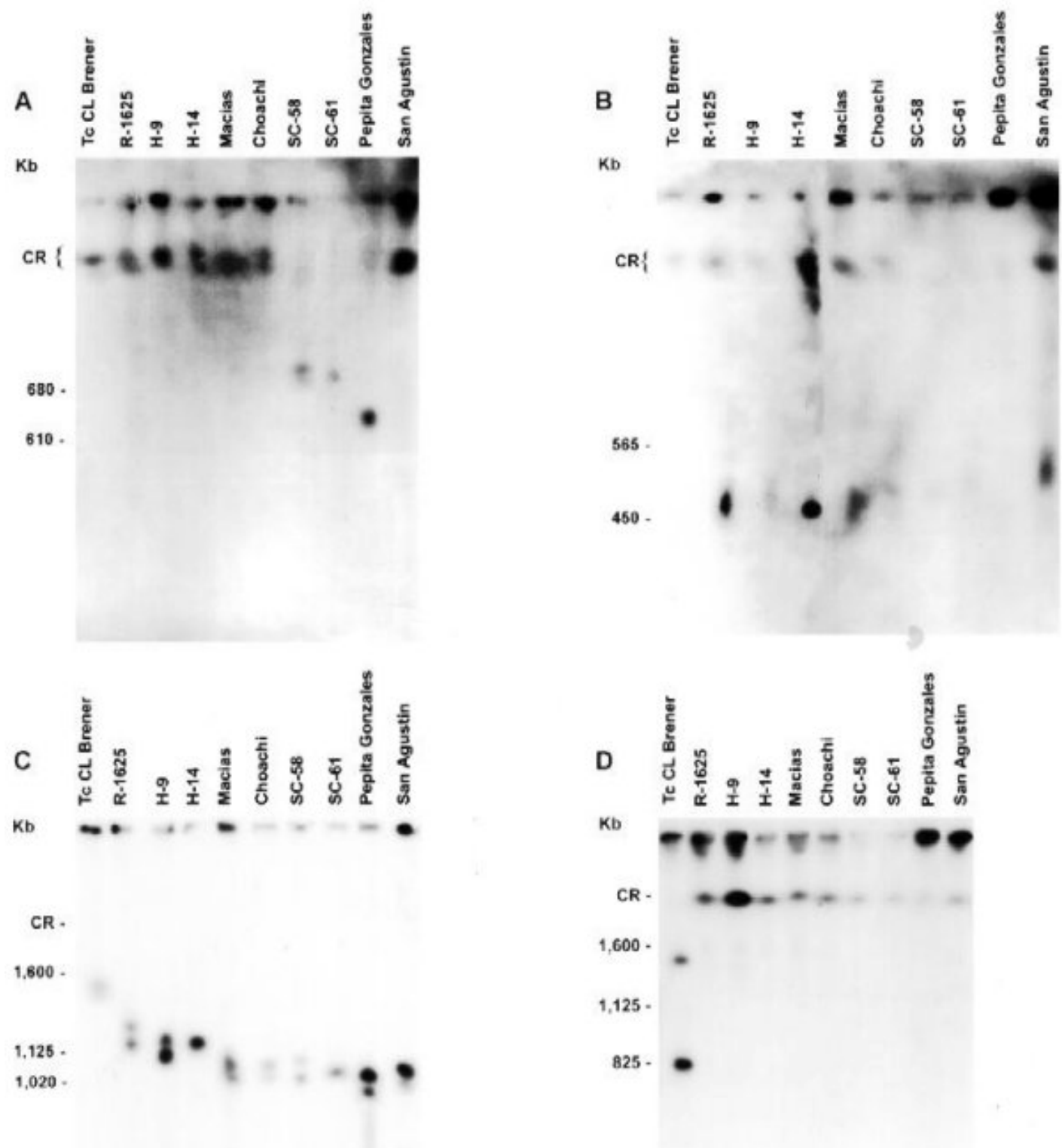

Fig. 3: chromosomal localization of $\beta$-tubulin, cysteine proteinase, hsp 70 and actin genes in Trypanosoma rangeli and T. cruzi. Southern blot hybridization with $\beta$-tubulin probe (A), cysteine proteinase probe (B), hsp 70 probe (C) and actin probe (D). The identity of samples, the chromosomes sizes and the electrophoretic conditions are described in the legend of Fig. 1. 


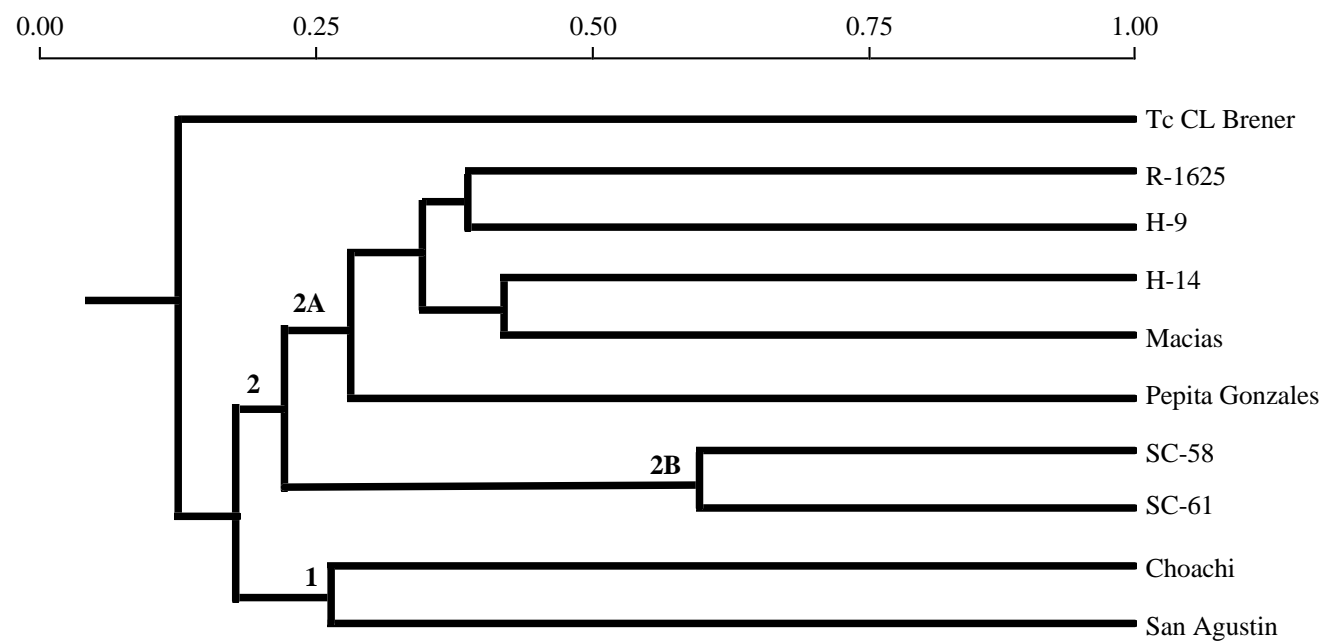

Fig. 4: phenogram produced by the unweighted pair-group method and Jaccard's similarity coefficient based on the molecular karyotype of Trypanosoma rangeli strains and the T. cruzi CL-Brener clone. For strains description, please refer to Table.

observed 14 chromosomal bands in a single $T$. rangeli strain studied.

The nine $T$. rangeli strains studied in the present work showed a variable number of chromosomal bands, from 16 to 24 , with sizes ranging from 390 $\mathrm{Kb}$ to $3130 \mathrm{~Kb}$. Also, chromosomal bands over $5700 \mathrm{~Kb}$ were observed as previously reported (Henriksson et al. 1996b) (data not shown). The absence of such large chromosomes in the T. cruzi reference clone is in agreement with other authors findings (Cano et al. 1995, Henriksson et al. 1995).

The karyotype variability observed in $T$. rangeli is characterized by the differences in both number and size of chromosomal bands among the different strains.

Thick chromosomal bands observed in all karyotypes may represent chromosomes of closely related size, which was not separated under our CHEF running conditions. Therefore, the total chromosome number may be higher than the observed in this study.

Another evidence of the complexity of the $T$. rangeli karyotype is the absence of chromosomes in some karyotype's regions which vary according to the strain analyzed. This observation can be clearly seen when comparing the karyotypes of $T$. rangeli strains isolated from Honduras ( $\mathrm{H}-9$ and H-14), Venezuela (Macias) and Colombia (Choachi).

Housekeeping genes fragments or anonymous markers have been used as probes to map T. cruzi chromosomes (Cano et al. 1995). Some of these DNA probes have shown to be useful markers to distinguish $T$. cruzi from $T$. rangeli strains
(Henriksson et al. 1996b). In the present work the chromosomal localization of cysteine proteinase, hsp 70 and actin genes allowed us to distinguish $T$. cruzi from $T$. rangeli strains.

The localization of $\beta$-tubulin genes separated $T$. rangeli strains in two distinct groups: one comprising the Brazilian strains (SC 58 and SC 61) and the Pepita Gonzales strain from Panama, and another comprising strains isolated from Honduras, El Salvador, Venezuela and Colombia. In the first group (SC-58, SC-61 and Pepita Gonzales strains) $\beta$-tubulin genes were detected in chromosomal bands from 650 to $720 \mathrm{~Kb}$, while in the second one, $\beta$-tubulin genes were present in chromosomal bands above $1000 \mathrm{~Kb}$. A weak hybridization with this gene probe was observed in the compression zone of gels (above $1000 \mathrm{~Kb}$ ) in T. rangeli SC 58, SC 61 and Pepita Gonzales strains, that may represent a small number of gene copies in a larger chromosome. This polymorphism observed among $T$. rangeli strains is in agreement with early reports from Macedo et al. (1993) using DNA fingerprinting, Steindel et al. (1994) using isoenzyme electrophoresis and RAPD, and Grisard et al. (1999a) using the mini-exon gene sequence analysis.

Cysteine proteinase genes were detected in $T$. cruzi CL-Brener clone only in large chromosomes (above $1000 \mathrm{~Kb}$ ). In contrast, we observed these genes in $T$. rangeli in large chromosomes and also in a $500 \mathrm{~Kb}$ chromosomal band, as previously described by Tanaka et al. (1994). One exception was Pepita Gonzales strain that showed these genes only in large chromosomes above $1000 \mathrm{~Kb}$. This variation in terms of chromosomal localization of cys- 
teine proteinase genes in different $T$. rangeli strains has already been pointed out by Martinez et al. (1995).

The hsp 70 genes were localized in $T$. rangeli strains in one or two chromosomal bands varying from 950 to $1200 \mathrm{~Kb}$, whereas in the T. cruzi CLBrener clone these genes were detected in a single $1500 \mathrm{~Kb}$ chromosomal band. Most of $T$. rangeli strains hybridized with the hsp 70 gene probe in two bands very close to each other.

The same was observed with the $\beta$-tubulin probe in a $T$. rangeli strain. These hybridization assays suggest that there are homologous chromosome pairs with different sizes in $T$. rangeli. As observed in T. cruzi and Leishmania sp., size polymorphisms between homologous chromosomes seems to be a very frequent phenomenon among trypanosomatids (Cruz et al. 1993, Henriksson et al. 1995).

$T$. rangeli actin genes are localized in a chromosomal band ranging from 2350 to $2700 \mathrm{~Kb}$, while in $T$. cruzi CL-Brener clone they were detected in two bands of $825 \mathrm{~Kb}$ and $1500 \mathrm{~Kb}$.

Although phenetic analysis of $T$. rangeli strains revealed a clear individuality, strains from the same or close geographical areas showed a greater similarity coefficient. Our results are in agreement with previous data based on DNA fingerprinting, RAPD and mini-exon gene sequences analysis that showed that $T$. rangeli populations from Southern Brazil are distinct from T. rangeli from Colombia, Venezuela and Honduras (Macedo et al. 1993, Steindel et al. 1994, Grisard et al. 1999a, Stevens et al. 1999).

Natural geographic barriers such as the Amazon rain forest and the Andes, as well as different triatomine vector species may have contributed for the polymorphism observed among strains isolated from Santa Catarina in Southern Brazil and the other T. rangeli strains from northern South and Central America (Macedo et al. 1993).

Since sexual reproduction is not known in these species other studies using a representative number of strains and as several markers as possible will be necessary in order to better understand the genetic variability of $T$. rangeli.

\section{ACKNOWLEDGEMENTS}

To Dr Alvaro Romanha who kindly provided Trypanosoma rangeli $\mathrm{H}-9$ and San Agustin strains. To Dr Elisa Cupolillo for helping on the numerical analysis. To Dr Ivar Pinheiro Aranha for reviewing the manuscript.

\section{REFERENCES}

Acosta L, Romanha AJ, Cosenza H, Krettli AU 1991. Trypanosomatid isolates from Honduras: differentiation between Trypanosoma cruzi and Trypanosoma rangeli. Am J Trop Med Hyg 44: 676-683.

Cano MI, Gruber A, Vazquez M, Cortés A, Levin MJ, González A, Degrave W, Rondinelli E, Zingales B,
Ramirez JL, Alonso C, Requena JM, Silveira JF 1995. Molecular karyotype of clone CL-Brener chosen for the Trypanosoma cruzi Genome Project. Mol Biochem Parasitol 71: 273-278.

Coura JR, Fernandes O, Arboleda M, Barrett TV, Carrara N, Degrave W, Campbell DA 1996. Human infection by Trypanosoma rangeli in the Brazilian Amazon. Trans R Soc Trop Med Hyg 90: 278-279.

Cruz AK, Titus R, Beverley SM 1993. Plasticity in chromosome number and testing of essential genes in Leishmania by targeting. Proc Natl Acad Sci USA 90: 1599-1603.

Cuba Cuba CA 1998. Revisión de los aspectos biológicos y diagnósticos del Trypanosoma (Herpetosoma) rangeli. Rev Soc Bras Med Trop 31: 207-220.

D'Alessandro A 1976. Biology of Trypanosoma (Herpetosoma) rangeli Tejera, 1920. In WHR Lumdsen, DA Evans (eds), Biology of Kinetoplastida, vol. I, London, p. 328-403.

D'Alessandro A, Saravia NG 1992. Trypanosoma rangeli. In JP Kreier, JR Baker (eds), Parasitic Protozoa, vol. II, Academic Press, London, p.1-54.

De Carvalho EF, De Castro FT, Rondinelli E, Soares CMA, Carvalho JFO 1990. Hsp 70 gene expression in Trypanosoma cruzi is regulated at different levels. J Cell Physiol 143: 439-444.

Grisard EC, Campbell DA, Romanha AJ 1999a. Miniexon gene sequence polymorphism among Trypanosoma rangeli strains isolated from distinct geographical regions. Parasitology 118: 375-382.

Grisard EC, Steindel M, Guarneri AA, Eger-Mangrich I, Campbell DA, Romanha AJ 1999b. Characterization of Trypanosoma rangeli strains isolated in Central and South America: an overview. Mem Inst Oswaldo Cruz 94: 203-209.

Henriksson J, Aslund L, Macina RA, Franke de Cazzulo BM, Cazzulo JJ, Frasch ACC, Pettersson U 1990. Chromosomal localization of seven cloned antigen genes provides evidence of diploidy and further demonstration of karyotype variability in Trypanosoma cruzi. Mol Biochem Parasitol 42: 213-224.

Henriksson J, Aslund L, Pettersson U 1996a. Karyotype variability in Trypanosoma cruzi. Parasitol Today 12: 108-114.

Henriksson J, Porcel B, Rydaker M, Ruiz A, Sabaj V, Galanti N, Cazzulo JJ, Frasch ACC, Pettersson U 1995. Chromosome specific markers reveal conserved linkage groups in spite of extensive chromosomal size variation in Trypanosoma cruzi. Mol Biochem Parasitol 73: 63-74.

Henriksson J, Solari A, Rydaker M, Sousa OE, Pettersson U 1996b. Karyotype variability in Trypanosoma rangeli. Parasitology 112: 385-391.

Holguín AF, Saravia NG, D’Alessandro A 1987. Lack of enzyme polymorphism in Trypanosoma rangeli stocks from sylvatic and domiciliary transmission cycles in Colombia. Am J Trop Med Hyg 36: 53-58.

Huang PL, Roberts BE, Mc Mahon-Pratt D, David JR, Miller JS 1984. Structure and arrangement of the $\beta$ tubulin genes of Leishmania tropica. Mol Cell Biol 4: 1372-1383.

Kemp DJ, Thompson JK, Walliker D, Corcoran LM 
1987. Molecular karyotype of Plasmodium falciparum: conserved linkage groups and expendable histidine-rich protein genes. Proc Natl Acad Sci USA 84: 7672-7676.

Kreutzer RD, Sousa OE 1981. Biochemical characterization of Trypanosoma spp. by isozyme electrophoresis. Am J Trop Med Hyg 30: 308-317.

Macedo AM, Vallejo GA, Chiari E, Pena SDJ 1993. DNA fingerprinting reveals relationships between strains of Trypanosoma rangeli and Trypanosoma cruzi. In SDJ Pena, R Chakraborty, JT Epplen, AJ Jeffreys (eds), DNA Fingerprinting: State of the Science, Birkhauser Verlag, Switzerland, p. 321-329.

Martínez J, Henriksson J, Rydaker M, Cazzulo JJ, Pettersson U 1995. Genes for cysteine proteinases from Trypanosoma rangeli. FEMS Microbiol Lett 129: 135-142.

Miles MA, Arias JR, Valente SAS, Naiff RD, Souza AA, Povoa MM, Lima JAN, Cedillos RA 1983. Vertebrate hosts and vectors of Trypanosoma rangeli in the Amazon Basin of Brazil. Am J Trop Med Hyg 32: 1251-1259.

Paixão JC 1995. Genes de Actina em Trypanosoma cruzi: Identificação, Organização e Análise dos Produtos Gênicos, PhD thesis, UFRJ, Rio de Janeiro, Brasil.

Schottelius J, Marinkelle CJ, Gomez-Leiva MA 1986. Comparative investigations of Latin American trypanosomes with lectins and complement lysis test. Trop Med Parasitol 37: 54-58.

Sousa MA 1999. Morphobiological characterization of Trypanosoma cruzi Chagas, 1909 and its distinction from other trypanosomes. Mem Inst Oswaldo Cruz 94: 205-210.

Southern EM 1975. Detection of specific sequences among DNA fragments separated by gel electrophoresis. J Mol Biol 98: 503-517.
Steindel M, Carvalho Pinto JC, Toma HK, Mangia RHR, Ribeiro-Rodrigues R, Romanha AJ 1991. Trypanosoma rangeli (Tejera, 1920) isolated from a sylvatic rodent (Echimys dasythrix) in Santa Catarina island, Santa Catarina state: first report of this trypanosome in Southern Brazil. Mem Inst Oswaldo Cruz 86: 7379.

Steindel M, Dias Neto E, Carvalho Pinto CJ, Grisard EC, Menezes CLP, Murta SMF, Simpson AJG, Romanha AJ 1994. Randomly amplified polymorphic DNA (RAPD) and isoenzyme analysis of Trypanosoma rangeli strains. J Eukaryot Microbiol 41: 261-267.

Steindel M, Murta SM, Carvalho Pinto CJ, Grisard EC, Romanha AJ 1992. The isoenzyme pattern of strains of Trypanosoma rangeli from different geographical regions. Mem Inst Oswaldo Cruz 87 (Suppl. II): 244.

Stevens JR, Teixeira MMG, Bngle LEH, Gibson WC 1999. The taxonomic position and evolutionary relationships of Trypanosoma rangeli. Int J Parasitol 29: 749-757.

Tanaka T, Kaneda Y, Iida A, Tanaka M 1994. Homologous cysteine proteinase genes located on two different chromosomes from Trypanosoma rangeli. Int J Parasitol 24: 179-188.

Traub-Cseko YM, Duboise M, Boukai LK, McMahonPratt D 1993. Identification of two distinct cysteine proteinase genes of Leishmania pifanoi axenic amastigotes using the polymerase chain reaction. $\mathrm{Mol}$ Biochem Parasitol 57: 101-115.

Vallejo GA, Marinkelle CJ, Guhl F, De Sanchez N 1988. Comportamiento de la infección y diferenciación morfologica entre Trypanosoma cruzi y $T$. rangeli en el intestino del vector Rhodnius prolixus. Rev Bras Biol 48: 577-587. 